\title{
Mapping Young Indians' Views Regarding the Acceptability of Surrogate Motherhood: A Pilot Survey*
}

\section{Cartografía de las posiciones de los jóvenes indios frente a la contratación de madres de alquiler: una encuesta piloto}

Received: 18 January 2018 | Accepted: 14 December 2018

\author{
Shanmukh Kamble ${ }^{a}$ \\ Karnatak University, India \\ ORCID: http://orcid.org/0000-0002-2185-8052 \\ SAngeEtha P. Mane \\ Karnatak University, India \\ Charlotte Petitfils \\ Jean-Jaurès University, France \\ Maria Teresa Muñoz Sastre \\ Jean-Jaurès University, France \\ Paul Clay Sorum \\ Albany Medical College, United States of America \\ ORCID: https://orcid.org/0000-0003-4009-9343
}

a Correspondence author. Email: anilhubs@gmail.com

How to cite: Kamble, S., Mane, S. P., Petitfils, C., MuñozSastre, M. T. \& Sorum P. C. (2019). Mapping young Indians' views regarding the acceptability of surrogate motherhood: A pilot survey. Universitas Psychologica, 18(3), 1-11. https://doi.org/10.11144/Javeriana. upsy18-3.myiv

\begin{abstract}
The objective was to map young Indians' views regarding the acceptability of surrogacy, and to delineate the circumstances under which surrogacy is considered as especially problematic. In India, the number of fertility clinics currently operating in the whole country is estimated at over 3,000 , making India the international leader in surrogacy. Very recently, however, surrogacy has become controversial. Participants $(N=430)$ were presented with scenarios depicting the circumstances in which a couple has contracted with a surrogate mother, and they were asked to indicate the extent to which such a contract may pose a moral problem. The scenarios involved four factors: the type of surrogacy (traditional or gestational), the mother's level of autonomy, the family context, and whether surrogacy was of the commercial or the altruistic kind. Four different personal positions were found: a group for which (a) surrogacy always posed a moral problem (22\%), (b) traditional surrogacy but not gestational surrogacy always posed a moral problem (15\%), (c) surrogacy did not pose a problem each time the husband agrees with the procedure $(40 \%)$, and (d) a group that chose not to express any position (23\%). Although surrogacy is legal and big business, young people's opinion seems to be divided on this issue. Even those who consider that surrogacy is not within itself an unacceptable procedure disagree regarding the conditions of its acceptability. This complex set of diverging attitudes, if replicated on large, representative samples, may explain the current government wavering on this issue and its recent decision that surrogacy services are forbidden for foreigners.

Keywords

India; surrogate motherhood; personal positions.
\end{abstract}




\section{RESUMEN}

Hemos realizado una cartografía de las posiciones de los jóvenes indios frente al problema de la contratación de madres de alquiler y hemos determinado las circunstancias bajo las cuales esa práctica podría ser considerada como problemática. En la India, el número de clínicas de fertilidad en funcionamiento es (por lo menos) de 3000 lo que hace por ahora de la India el líder internacional en contratación de madres de alquiler. No obstante, la contratación de madres de alquiler ha llegado a ser, en este país, una práctica controvertida. Los participantes en este estudio $(\mathrm{N}=430)$ examinaron distintos escenarios describiendo las circunstancias en las cuales una pareja ha contratado una madre de alquiler e indicaron la medida en la cual un tal contrato plantea un problema moral. Los escenarios estaban construidos en función de cuatro factores: el tipo de contratación (tradicional o gestacional), el grado de autonomía personal de la madre, el contexto familiar y si la contratación era comercial o altruista. Tres posiciones personales fueron encontradas. Para 22\% de los participantes, la contratación de madres de alquiler plantea siempre un problema moral; para $15 \%$, la contratación plantea un problema moral cuando es de tipo tradicional, y (c) para 40\%, la contratación no plantea un problema moral si el marido está de acuerdo. El resto de los participantes (23\%) no expreso ninguna posición. Aunque la contratación de madres de alquiler es legal en la India y corresponde con un negocio de alto provecho, la opinión de los jóvenes sobre su aceptabilidad moral parece dividida. Incluso las personas que consideran que la contratación no es, en sí mismo, una práctica inaceptable no están de acuerdo entre ellos sobre las condiciones de su aceptabilidad. Este complejo conjunto de actitudes, si se replica en muestras más amplias y más representativas, podría explicar porque el gobierno Indio está cambiando de posición sobre ese tipo de negocio y porque ha tomado recientemente la decisión de prohibir a los extranjeros el acceso a las clínicas.

Palabras clave

India; contratación de madres de alquiler; posiciones personales.

Surrogacy 'occurs when a couple, the intended parents, contracts with a woman to carry a child for them and to relinquish that child to them after birth' (Ciccarelli \& Beckman, 2005 , p. 22). Two types of surrogacy are usually distinguished: (a) traditional surrogacy - when one of the surrogate mother's eggs is fertilized by the intended father's sperm, and (b) gestational surrogacy - when one of the commissioning mother's eggs is fertilized in vitro, and the embryo is transferred into the surrogate mother's womb. The contract can be either commercial or altruistic depending on whether the surrogate mother is paid (beyond expenses) or not.

In most countries, these practices are regulated by law. Commercial surrogacy has been legalized in Georgia, Israel, Russia, Ukraine, and many US states (All about surrogacy, 2015). Altruistic surrogacy is currently permitted in Australia, Belgium, Belorussia, Brazil, Canada (except Quebec), Denmark, Greece, the Netherlands, New Zeeland, Portugal, Russia, Ukraine, SouthAfrica, Sweden, Thailand, the United Kingdom, and Vietnam. Nevertheless, the set of conditions under which surrogacy is considered legal varies considerably from one country to another (Petitfils, Muñoz Sastre, Sorum, \& Mullet, 2017). For example, in Israel, commercial surrogacy is legal but altruistic surrogacy is not permitted because it is assimilated to adultery (Reilly, 2007). In contrast, in the United Kingdom, altruistic surrogacy is legal whereas commercial surrogacy is not permitted because it is considered an exploitation of the women's body. In Brazil, surrogacy is allowed only among relatives.

In India, commercial surrogacy was legal until 2015 (Baby Manji Yamada vs. Union of India \& ANR, 2008). The number of fertility clinics currently operating in the whole country was estimated at over 3,000, and the annual business at $\$ 400$ million (Bhalla $\&$ Thapliyal, 2013), making India the leader in international surrogacy (In International surrogacy laws, 2015). The Law Commission of India (2009) submitted in 2009 a report on assisted reproductive technology that mandated (a) that the surrogate mother's informed consent to bear the child be obtained, (b) that at least one of the intended parents' gametes be used, (c) that the surrogate mother's husband (and other family members) agree with the procedure, and (c) that the surrogate mother be compensated reasonably for all expenses involved in carrying the child to term, including life insurance for the surrogate mother, although commercial surrogacy, while legal, is not encouraged. Very recently, surrogacy has become controversial and the government has banned contracts with foreigners seeking Indian surrogates (World real matters, 2015). 


\section{Opinions regarding surrogacy}

Ciccarelli and Beckman found in their 2005 review of assisted reproductive technologies that those involving third parties (including surrogates) were less acceptable than all others, especially if they were remunerated. In subsequent studies, the rate of approval considerably varied according to the country. It was high in Iran, where Shiite scholars publicly supported it: It was approved by $90 \%$ of infertile women living in Tabriz (Rahmani et al., 2011) and by $53 \%$ of female and $55 \%$ of male members of infertile couples in Hamadan (Mohebbi Kian, Riazi, \& Bashirian, 2014). Also, in a study conducted among fertile women in East Azerbaijan, $82 \%$ of them considered that surrogacy should be legal, while only $3 \%$ declared that surrogacy causes ethical problems for society, and only $7 \%$ viewed payment of surrogate mothers as distasteful (Rahmani et al., 2014).

In contrast, in Ibadan, Nigeria, only $38 \%$ of a sample of infertile women would agree to surrogacy, and most of these opposed paying the surrogate (Bello, Akinajo, \& Olayemi, 2014). Moreover, in Ankara, Turkey, only 15\% (Baykal, Korkmaz, Ceyhan, Goktolga, \& Baser, 2008) of infertile women would agree to surrogacy and only 24\% (Kilic et al., 2009) had positive attitudes toward it. In addition, in Japan, among infertile couples, only $17 \%$ of women and $23 \%$ of men would have recourse to gestational surrogacy and only $7 \%$ and $8 \%$, respectively, to traditional surrogacy (Saito \& Matsuo, 2009), although 50\% of a general sample of adults, especially those expressing a liberal attitude toward gender roles, approved gestational surrogacy (Suzuki et al., 2006).

\section{The present study}

The present study was exploratory. It was aimed to map young Indians' views regarding the acceptability of surrogacy and to delineate the circumstances under which surrogacy is considered especially problematic. The sample was composed of students because, before launching a full scale study on this very sensitive issue -- a study involving large samples of adults, it was considered necessary to explore its feasibility in terms of people's reactions and willingness to participate.

Owing to current legislation, the study was restricted to the case in which an Indian couple of commissioners have contracted with an Indian surrogate mother. The study was motivated by the fact that, as illustrated above, (a) legislation regarding surrogacy is very disparate from country to country, (b) people's opinions regarding its acceptability seem to vary as a function of the type of surrogacy and the surrogate mother's characteristics, and (c) no study to date has explored Indians' views on this issue although the issue has been much debated in the country.

The present study used the same technique as the one implemented in France by Petitfils et al. (2017). In this study, participants were presented with a number of realistic scenarios depicting the circumstances in which an infertile couple has contracted with a surrogate mother, and they were requested to assess the extent to which such a contract would be morally problematic. Four factors were considered: (a) type of surrogacy (fertilization by sperm or by transfer of an embryo), (b) surrogate mother's level of autonomy (e.g., has a job and fully understands the process), (c) surrogate mother's family situation (e.g., single without a child), and (d) level of compensation associated with identity of the surrogate (e.g., payment of $€ 5000$ to a cousin). Through cluster analysis, three qualitatively different personal positions were found: (a) a minority group (14\%) for which maternal surrogacy does not systematically present a moral problem, (b) a majority group for which surrogacy often (34\%) or always (30\%) presents a moral problem, (b) and (c) a group (22\%) for which circumstances - mainly the family context and the mother's level of autonomy were completely determining.

It was not necessary to alter the scenarios created by Petitfils et al. (2017) because the four factors listed above perfectly fit the main 
considerations expressed in the report on assisted reproductive technology issued by the Law Commission of India (2009), namely (a) whether the surrogate mother has the capability to express consent to bear a child to full term, (b) whether gestational or traditional surrogacy is under consideration, (c) whether the surrogate mother's husband agrees with the procedure (or the mother is still single), and (d) the extent to which the expenses for carrying are compensated, and the mother has been paid.

We expected to find, in our sample of students, qualitatively different ethical positions. First, we expected to find, as in Petitfils et al. (2017): (a) a group of students for which maternal surrogacy always poses a moral problem and (b) a group of students for which maternal surrogacy never poses a big moral problem, irrespective of circumstances. Although the 'always a problem' position was the majority position in most studies conducted on samples of lay people from different countries (Ciccarelli \& Beckman, 2005), we nevertheless expected, owing to the current situation in India, this group not to be the majority group.

Second, we expected to find, as in Petitfils et al. (2017) a group of students whose opinion is determined by the concrete circumstances of surrogacy. In this group, the more the person is autonomous (e.g., the person is able to fully understand the procedure and is not financially deprived), the more the gametes come from both intended parents, and the more the family context is favorable (the surrogate mother's husband does not object to the procedure), the less the recourse to maternal surrogacy would be viewed as a moral problem. We expected this group to be the majority group.

\section{Method}

\section{Participants}

Four hundred thirty unpaid students (275 females and 155 males) participated in the present study. All of them were Indians from three religious communities: Hindu $(N=392)$,
Muslim $(N=9)$, and Christian $(N=29)$. Their mean age was 22.35 years $(\mathrm{SD}=1.66$, range $=20-32$ years). All participants were enrolled at Karnatak University, Dharwad. Their fields of studies are shown in Table 1.

\section{Material}

The material consisted of 54 realistic scenarios that were, as indicated earlier, composed according to a four-factor within-subject design: Type of surrogacy (fertilization by sperm or by transfer of an embryo) x Surrogate mother's level of autonomy (has no job and doesn't fully understand the process, has no job and fully understands, or has a job and fully understands) $\mathrm{x}$ Surrogate mother's family situation (single without child, married with two children and the husband agrees with the process, or married with two children and the husband objects) $\mathrm{x}$ Level of compensation (fully altruistic, Rs. 15,000 to a cousin or Rs. 60,000 to a non-relative).

A concrete example of a story is the following: "Mrs. and Mr. Desai (an Indian couple) would like to have a child but they have trouble engendering one. They have asked Mrs. Dubay whether she would agree to bear the child. Mrs. Dubay is 26 years old. She fully understands the procedure and she has full capacity to refuse or to accept. She is currently unemployed. She is not a relative of Mrs. Desai. She would be remunerated up to Rs. 60,000 . Her husband does not object. The embryos that would be transferred are from Mrs. and Mr. Desai. If Mrs. Dubay agrees, to what extent do you think that this poses a moral problem"? 
Table 1

Demographic Characteristics of the Sample and of Each Cluster

\begin{tabular}{lrrrrr}
\hline \multirow{2}{*}{ Characteristic } & \multicolumn{5}{c}{ Cluster } \\
\cline { 2 - 5 } & $\begin{array}{c}\text { Type of } \\
\text { Surrogacy }\end{array}$ & $\begin{array}{c}\text { Family } \\
\text { Context }\end{array}$ & $\begin{array}{c}\text { Always a } \\
\text { Problem }\end{array}$ & Undetermined & Total \\
\hline Gender : $\chi^{2}(3)=29.89, p<0.001$ & & & & & \\
Males & $10(6)$ & $69(43)$ & $26(17)$ & $50(33)$ & 155 \\
Females & $56(20)$ & $100(36)$ & $74(27)$ & $45(16)$ & 275 \\
Religion : $\chi^{2}(6)=10.73, p=0.10$ & & & & & \\
Hindu & $65(17)$ & $156(40)$ & $88(22)$ & $83(21)$ & 392 \\
Muslim & $1(11)$ & $4(44)$ & $3(33)$ & $1(11)$ & 9 \\
Christian & $0(0)$ & $9(31)$ & $9(31)$ & $11(38)$ & 29 \\
Field of study: $\chi^{2}(18)=111.96, p<0.001$ & & & & \\
Mathematics & $15(32)$ & $20(43)$ & $6(13)$ & $6(13)$ & 47 \\
Physics \& Chemistry & $17(16)$ & $42(40)$ & $35(34)$ & $10(10)$ & 104 \\
Life Sciences & $22(32)$ & $16(23)$ & $23(33)$ & $8(12)$ & 69 \\
Earth Sciences & $0(0)$ & $1(11)$ & $0(0)$ & $8(89)$ & 9 \\
Psychology \& Social Sciences & $3(3)$ & $34(35)$ & $25(26)$ & $36(37)$ & 98 \\
Economy \& Trade & $4(18)$ & $9(41)$ & $4(18)$ & $5(23)$ & 22 \\
Literature & $5(6)$ & $47(58)$ & $7(9)$ & $22(27)$ & 81 \\
Total & $66(15)$ & $169(40)$ & $95(22)$ & $100(23)$ & 430 \\
\hline & & & & & \\
\hline
\end{tabular}

The response scale was an 11-point scale with a right-hand anchor of "Certainly yes, a big moral problem" (coded 10) and a left-hand anchor of "Not at all a moral problem" (coded 0). The cards were arranged by chance. The order was different for each participant.

\section{Procedure}

Each participant was tested individually or in groups of three to four in a quiet place at the university. Testing was conducted according to Anderson's (2008; 2016; 2018) recommendations. The participants took 30-45 minutes to complete the ratings. They knew in advance how long the experiment would last. None of them complained about the number of vignettes they were required to evaluate or about the credibility of the proposed situations. The study conformed to usual ethical standards in India: Full anonymity was respected and informed consent was obtained from all participants in the study. It was approved by the Ethics Committee of Karnatak University, Dharwad.

\section{Results}

The mean acceptability ratings and standard deviations for each scenario are shown in Annex A. A cluster analysis was performed on the raw data using the procedure advocated by Hofmans and Mullet (2013, see also Sedkaoui \& Mullet, 2016). Four clusters were identified. Two of them are shown in Figure 1. A set of four ANOVAs was performed on the data from each cluster with a design of Type $\mathrm{x}$ Autonomy $\mathrm{x}$ Family Status $\times$ Compensation, $2 \times 3 \times 3 \times 3$. Owing to the great number of comparisons (15), the significance threshold was, using the Bonferroni technique, set at $0.003(0.05 / 15)$. The results of the ANOVA are shown in Annex B.

The first cluster ( $15 \%$ of the sample) was called Type of Surrogacy because this factor had by far the strongest effect. Ratings were considerably higher when sperm were used $(M=8.14)$ than when an embryo was transferred $(M=4)$. They were slightly higher (a) when the surrogate mother was not autonomous $(M=6.87)$ than when she was $(M=5.66$ and 5.70), and (b) when the surrogate mother's husband objected $(M=6.48)$ or she was single $(M=6.52)$ than when the surrogate husband did not object $(M=5.22)$. The Type $x$ Autonomy interaction was significant. The autonomy effect was weaker when sperm were used $(8.47-7.93=0.54)$ than when an embryo was transferred (5.26 - 3.36 $=1.90)$. The Type $\mathrm{x}$ Family Status interaction was significant (depicted in Figure 1, top panels). Three other interactions were also significant, although their effect sizes were weaker; detailed results are available from the corresponding author.

The second cluster (39\%) was called Family Context because this factor had the strongest effect. Ratings were higher when the surrogate mother's husband objected $(\mathrm{M}=6.48)$ than when he did not $(M=3.87)$. Ratings were medium when the surrogate mother was single $(M=5.66)$. Ratings were also higher (a) when sperm were used $(M=5.78)$ than when an embryo was transferred $(M=4.90)$, and $(b)$ when the surrogate mother was not autonomous $(M=6.11)$ than when she was $(M=4.93$ and 4.97). The Type $x$ Family interaction was significant. It is depicted in Figure 1 (bottom panels).

The third cluster (23\%, not shown) was the expected Always a Big Moral Problem cluster because all ratings were high $(M=8.05)$. Ratings 
were still higher (a) when sperm were used $(M$ $=8.46)$ than when an embryo was transferred $(M=7.65)$, (b) when the surrogate mother was not autonomous $(M=8.36)$ than when she was $(M=7.88$ and 7.93), and (c) when the surrogate mother's husband objected $(M=8.54)$ than in the other cases $(M=7.67$ and 7.96). The Type $\mathrm{x}$ Family Status interaction was significant. The family effect was weaker when sperm was used $(8.75-8.15=0.60)$ than when an embryo was transferred $(8.33-7.18=1.15)$. The Autonomy $\mathrm{x}$ Family Status interaction was also significant. The family effect was weaker when the mother was not autonomous $(8.63-8.13=0.50)$ than when she was $(8.62-7.52=1.10)$.
Figure 1

Ratings of maternal surrogacy as a moral problem as a function of surrogate mother's level of autonomy, family status, and type of surrogacy.
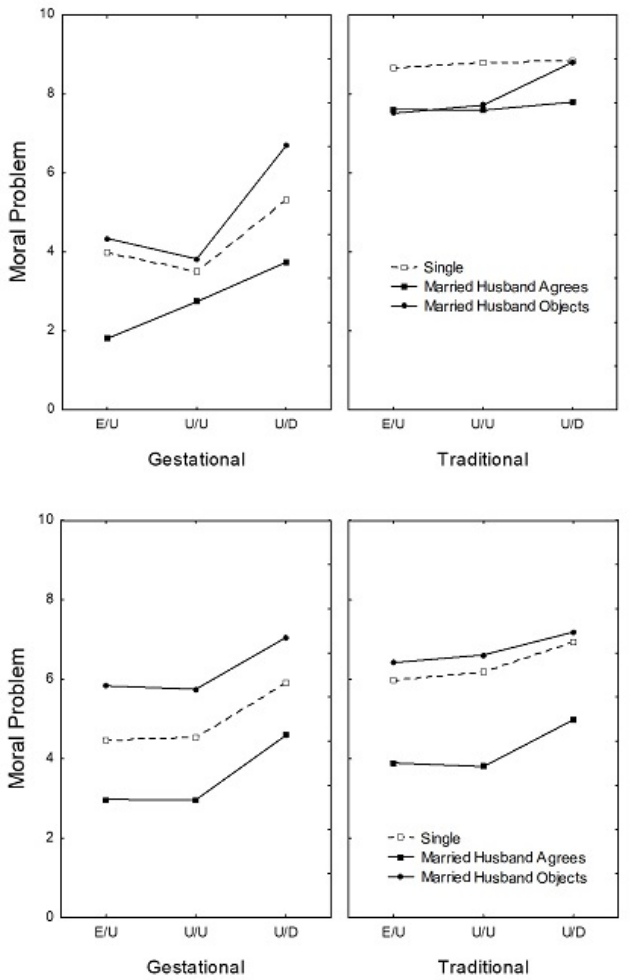

Ratings are on the $y$-axis. Surrogate mother's level autonomy is on the $\mathrm{x}$-axis $(\mathrm{E} / \mathrm{U}=$ Employed and understands the procedure, $\mathrm{U} / \mathrm{U}=$ Unemployed and understands, $\mathrm{U} / \mathrm{D}=$ Unemployed and doesn't fully understand). The three curves express the surrogate mother's family status. The two panels correspond to the two types of surrogacy. The two rows correspond to the Type of Surrogacy and Family Context clusters.

The fourth cluster (22\% of the sample) was called Undetermined mainly because all ratings were close to the middle of the response scale $(M=5.10)$. Ratings were slightly higher when financial compensation was low $(M=5.32)$ than when it was high $(M=$ $4.87)$ or in the case of altruistic surrogacy $(\mathrm{M}=5.11)$. As shown in Table 1 , male participants were significantly more frequently members of the Undetermined cluster than female participants, and females participants were more frequently members of the Always a Big Moral Problem and the Type of Surrogacy clusters 
than male participants. Also, (a) psychologists, social scientists and earth scientists were more frequently members of the Undetermined cluster, (b) physicists and life scientists were more frequently members of the Always a problem cluster, (c) mathematicians and life scientists were more frequently members of the Type of surrogacy cluster, and (d) participants studying literature were more frequently members of the Family context cluster, than other participants.

An ANOVA with a design of Cluster $x$ Type $\mathrm{x}$ Autonomy x Family Status x Compensation, 4 x $2 \times 3 \times 3 \times 3$ was also performed. The main results are shown in Table 3. Ratings were higher in the case of traditional surrogacy $(M=6.87)$ than in the case of gestational surrogacy $(\mathrm{M}=$ 5.42). Post-hoc analyses showed that ratings were higher (a) when the surrogate mother was not autonomous $(M=6.58)$ than in the two other cases $(M=5.91$ and 5.93), (b) when the husband objected $(M=6.63)$ than when the surrogate mother was single $(M=6.36)$, (c) when she was single than when the husband did not object ( $M$ $=5.43)$, and $(\mathrm{d})$ when remuneration was low $(\mathrm{M}$ $=6.28)$ than in both other cases $(M=6.11$ and $6.03), p<0.001$. The five significant interactions involving the Cluster factor were consistent with results observed at the cluster level.

An ANOVA with a design of Country (India vs. France) x Type x Autonomy x Family Status x Compensation, $2 \times 2 \times 3 \times 3 \times 3$ was finally performed, using the data gathered by Petitfils et al. (2017) in addition to the present ones. Age and gender were entered in the analysis as covariates. Ratings were lower among Indian $(M=5.48)$ than among French participants $(M$ $=6.65), F(1,655)=23.55, p<0.001, \eta_{p}^{2}$ $=0.03$. The autonomy factor had more impact among French $(8.17-5.57=2.60)$ than among Indians participants $(5.80-5.57=0.23), F(2$, $1310)=204.63, p<0.001, \eta_{p}^{2}=0.24$. These significant effects involving the Country factor were consistent with results observed at the cluster level in both studies.

\section{Discussion}

We have, as in Petitfils et al. (2017), found qualitatively different positions but these positions were not fully similar to the ones in the French study. In both studies, a group of participants for which maternal surrogacy always pose a big moral problem was identified. Nevertheless, this group was not, and as expected, the majority group (23\% in the present study vs. 63\% in Petitfils et al. (2017). This suggests that most young people in India are, as people in the neighboring country of Iran (Rahmani et al., 2014), not radically hostile to the procedure. Females were more frequently members of this group than males.

As expected, a group of participants (55\%) for which surrogacy does not systematically pose a moral problem was found. This group was however split in two subgroups. For some of these participants (15\%), mostly females, the major criterion of acceptability was the type of surrogacy (gestational or traditional). When both sets of gametes were from the intended parents, gestational surrogacy was not seen as posing a moral problem provided that the surrogate's husband agreed with the procedure, and even when the surrogate mother was not fully able to understand it. When one set of gametes was from the surrogate mother (traditional surrogacy), however, surrogacy was always seen as posing a moral problem. This finding was consistent with the assertion in the report by the Law Commission of India (2009, p. 26) that "bond of love and affection with a child primarily emanates from biological relationship". Females were more frequently members of this group than males; they may feel that it would be more difficult to relinquish one's own biological child to strangers than a child with whom no genetic link exists.

For the remaining participants (40\%), the criterion of acceptability was the family context, in association with the surrogate mother's level of autonomy and the type of surrogacy. Each time the surrogate mother's husband agreed with the procedure, surrogacy of both types were not viewed as posing a moral problem except 
when the surrogate mother was not fully able to understand the procedure.

A group of "undetermined" participants was also found, mostly males. Such a group of participants has been already found in a study on the issue of ending the lives of newborns conducted in India (Kamble, Ahmed, Sorum, \& Mullet, 2014, see also Mullet et al., 2016). The fact that about one fifth of the sample chose not to express any opinion is somewhat surprising since, contrary to the issue of damaged newborns, the issue of maternal surrogacy has, in India, been debated for quite a while (Mukherjee, 2007). Many students may have felt that they were not directly concerned by the issue or may have felt that they were not informed enough.

This finding provides, however, an important methodological lesson: if, for example, only one scenario had been used - for example, of a single female able to understand the procedure of gestational surrogacy - the responses of participants from the undetermined cluster and of those from the family context cluster would have been indistinguishable. Having participants respond to multiple, structured scenarios allowed us to distinguish the absence of opinion from medium support and to correctly classify people as a function of their opinions.

Several additional issues must be discussed. The first one is related to the weakness of the effect of the surrogate mother's level of autonomy compared to the effects of the type of surrogacy and the family context. Although this result was fully consistent with previous findings from studies on ethical issues conducted in India (Kamble, Sorum, \& Mullet,, 2012; Kamble et al., 2014), it raises the question of the relevance of the autonomy principle of bioethics (Beauchamp $\&$ Childress, 2008) in communitarian societies such as India (Crawford, 2003). The concern of some Indian physicians that far "from empowering a woman", maternal surrogacy "represents loss of choice, loss of autonomy, loss of control" might be well grounded (Patel \& Rao, 2014, p. 32).

The second issue is related to the weakness of the effect of the compensation factor, as compared with its effect among French. This finding is interesting in regards to the importance given to monetary compensation among Western politicians: In countries such as the United Kingdom or the state of New York, commercial surrogacy is clearly distinguished from altruistic surrogacy and completely prohibited. Among young Indians, and on the moral level, this distinction seems not to hold: Commercial surrogacy does not pose a greater problem than altruistic surrogacy. This finding is consistent with considerations that have been expressed in the Indian press by managers of IVF clinics: "Domestic "labour should be paid, so when reproduction and pregnancy becomes a job, we will look at the value of female labour in a new light. This would elevate women's status in a patriarchal capitalist society" (Patel \& Rao, 2014, p. 31).

The third issue is related to the strong effect of the field-of-studies variable on participants' positions. This effect, which was largely unexpected, is difficult to interpret. It suggests that the strong individual differences that have been found in this study may be linked to participants' personality and values. Indeed, career choice is not simply determined by general intelligence and good grades in sciences or in arts; it, logically, depends on personal interests (Athanasou \& van Esbroeck, 2008). Life sciences students were, more often than others, found in the type of surrogacy cluster; perhaps these students, owing to their training in biology, tended more than others to give weight to physiological factors. Psychology students were, more often than others, found in the undetermined cluster; perhaps these students, owing to their training, were, more than others, torn between the two conflicting views expressed earlier: surrogacy as empowerment of women versus surrogacy as exploitation of the poor (Patel \& Rao, 2014). Future studies should more closely link ethical views with personality and value measurements in order to more completely understand what can appear as starkly contrasting views about ethical issues. 
Implications

Although maternal surrogacy is legal and big business in India, public opinion in this country, as far as it can be inferred from the opinion of a sample of students, seems to be divided on this issue. A little bit more than half of the students who participated in the study agreed with the view that surrogacy was not within itself an unacceptable procedure but they, however, disagreed among them regarding the conditions of its acceptability. Some were of the opinion that traditional surrogacy always poses a moral problem because the surrogate mother is doubly involved in the procedure; that is, she also provides one set of gametes. Others were of the opinion that traditional surrogacy does not pose a moral problem as long as the surrogate mother's husband agrees with the procedure, and the surrogate mother fully understands the procedure. The remaining students considered that surrogacy always posed a moral problem or they confessed their complete indetermination regarding the issue. This complex set of diverging attitudes regarding surrogacy, if replicated on a larger and more representative sample, may explain the current government wavering on this issue, and its recent decision that surrogacy services for foreigners are banned despite the hard hit it should represent to this booming industry.

\section{References}

All about surrogacy. (2015). Retrieved from http://www.creativefamilyconnection s.com/\#!surrogacy-law-by-state/f49jq

Anderson, N. H. (2008). Unified social cognition. New York, NY: Psychology Press.

Anderson, N. H. (2016). Information Integration Theory: Unified Psychology based on three mathematical laws. Universitas Psychologica, 15(3), 1-7. http://dx.doi.org/10.11144/Jave riana.upsy15-3.iitu

Anderson, N. H. (2018). Moral science. New York, NY: Psychology Press.
Athanasou, J. A., \& van Esbroeck, R. (Eds.) (2009). International handbook of career guidance. New York, NY: Springer. https://d oi.org/10.1007/978-1-4020-6230-8

Baby Manji Yamada vs. Union of India \& ANR. (2008). Retrieved from http://indiankanoo n.org/doc/854968/

Beauchamp, T. L., \& Childress, J. F. (2008). Principles of biomedical ethics $\left(6^{\text {th }} \mathrm{ed}\right.$.). New York, NY: Oxford University Press.

Bello, F. A., Akinajo, O. R., \& Olayemi, O. (2014). In-vitro fertilization, gamete donation and surrogacy: perceptions of women attending an infertility clinic in Ibadan, Nigeria. African Journal of Reproductive Health, 18(2), 127-133. Retrieved from https://www.ajrh.info/index .php/ajrh/article/view/181

Bhalla, N., \& Thapliyal, M. (2013). Foreigners are flocking to India to rent wombs and grow surrogate babies. Retrieved from http://www.businessinsider.com/india -surrogate-mother-industry-2013-9\#ixzz3 XSIDAd94

Baykal, B., Korkmaz, C., Ceyhan, S., Goktolga, U., \& Basser, I. (2008). Opinions of infertile Turkish women on gamete donation and gestational surrogacy. Fertility and Sterility, 89(4), 817-822. https://doi.org/10.1016/j.fe rtnstert.2007.04.022

Ciccarelli, J. C., \& Beckman, L. J. (2005). Navigating rough waters: An overview of psychological aspects of surrogacy. The Journal of Social Issues, 61 (1), 21-43. https:// doi.org/10.1111/j.0022-4537.2005.00392.x

Crawford, S. C. (2003). Hindu bioethics for the Twenty-first Century. Albany, NY: State University of New York Press.

Hofmans, J., \& Mullet, E. (2013). Towards unveiling individual differences in different stages of information processing: A clustering-based approach. Quality $\mathfrak{E}$ Quantity, 47(1), 455-464. https://doi.org/10 $.1007 / \mathrm{s} 11135-011-9529-7$

International surrogacy laws (2015). Retrieved from http://www.familylaw.com.ua/index.p hp?option $=$ com_content $\&$ view $=$ article $\&$ $\mathrm{id}=69 \&$ Itemid $=99 \&$ lang $=\mathrm{en}$ 
Kamble, S., Ahmed, R., Sorum, P. C., \& Mullet, E. (2014). The acceptability among young Hindus and Muslims of actively ending the lives of newborns with genetic defects. Journal of Medical Ethics, 40(3), 186-191. http://dx.doi.org/10.1136/medeth ics-2012-100934

Kamble, S., Sorum, P. C., \& Mullet, E. (2012). Young Indians' views of the acceptability of physician-assisted suicide. International Perspectives in Psychology: Research, Practice, Consultation, 1(3), 165-176. http://dx.doi.o $\mathrm{rg} / 10.1037 / \mathrm{a} 0029380$

Kilic, S., Ucar, M., Yaren, H., Gulec, M., Atac, A., Demirel, F. ... Demirel, O. (2009). Determination of the attitudes of Turkish infertile women towards surrogacy and oocyte donation. Pakistan Journal of Medical Science, 25(1), 36-40. Retrieved from https://pjms.com.pk/issues/janmar09/ article/article6.html

Law Commission of India. (2008). Need for legislation to regulate assisted reproductive technology clinics as well as rights and obligations of parties to a surrogacy. Retrieved from http://lawcommissionofindia.nic.in/re ports/report228.pdf

Mohebbi Kian, E., Riazi, H., \& Bashirian, S. (2014). Attitudes of Iranian infertile couples toward surrogacy. Journal of Human Reproductive Sciences, 7(1), 47-51. https://d oi.org/10.4103/0974-1208.130847

Mukherjee, K. (2007). Rent-a-womb in India fuels surrogate motherhood debate. Retrieved from http://www.reuters.com/article/2007/ 02/04/us-india-surrogacy-idUSDEL298735 20070204.

Mullet, E., Kpanake, L., Kamble, S., Ahmed, R. A., Bugay, A., Muñoz Sastre, M. T., \& Sorum, P. C. (2016). Mapping people's views regarding physician assisted suicide: A five-country study. International Psychology Bulletin, 20, 16-25.

Patel, N., \& Rao, M. (2014). Is surrogacy a legitimate way out of poverty? New Internationalist, 11, 29-32. Retrieved from https://newint.org/sections/argument/ 2014/11/01/argument-surrogacy-poverty
Petitfils, C., Muñoz Sastre M. T., Sorum, P. C., \& Mullet, E. (2017). Mapping people's views regarding the acceptability of surrogate motherhood. Journal of Reproductive and Infant Psychology, 35(1), 65-76. https://doi. org/10.1080/02646838.2016.1222358

Rahmani, A., Howard, F., Sattarzadeh, N., Ferguson, C., Asgari, A., \& Ebrahimi, H. (2014). Viewpoints of fertile women on gestational surrogacy in East Azerbaijan Province, Iran. Indian Journal of Medical Ethics, 11(1), 29-33. https://doi.org/10.205 29/IJME.2014.008

Rahmani, A., Sattarzadeh, N., Gholizadeh, L., Sheikhalipour, Z., Allahbakhshian, A., \& Hassankhani, H. (2011). Gestational surrogacy: Viewpoint of Iranian infertile women. Journal of Human Reproductive Sciences, 4(3), 138-142. https://doi.org/10.4 103/0974-1208.92288

Reilly, D. R. (2007). Surrogacy pregnancy: A guide for Canadian prenatal health care providers. Canadian Medical Association Journal, 176(4), 483-485. https://doi.org/10 $.1503 /$ cmaj.060696

Saito,Y., \& Matsuo, H. (2009). Survey of Japanese infertile couples' attitudes toward surrogacy. Journal of Psychosomatic Obstetrics $\mathcal{E}$ Gynecology, 30(3), 156-161. ht tps://doi.org/10.1080/01674820802429435

Sedkaoui, H., \& Mullet, E. (2016). Mapping French people's views on chemical castration of child and adolescent sex offenders. Universitas Psychologica, 15(3), 1-7. https://doi.org/10.11144/Javeriana.ups y15-3.mfpv

Suzuki, K., Hoshi, K., Minai, J., Yanaihara, T., Takeda, Y., \& Yamagata, Z. (2006). Analysis of national representative opinion surveys concerning gestational surrogacy in Japan. European Journal of Obstetrics and Gynecology and Reproductive Biology, 126(1), 39-47. https://doi.org/10.1016/j.ejo grb.2005.07.030

World real matters. (2015). Retrieved from http://www.worldmag.com/2015/11/i ndia_moves_to_ban_surrogacy_for_foreig n_couples 


\section{Annex A}

\section{Means and Standard Deviations Observed for Each Scenario}

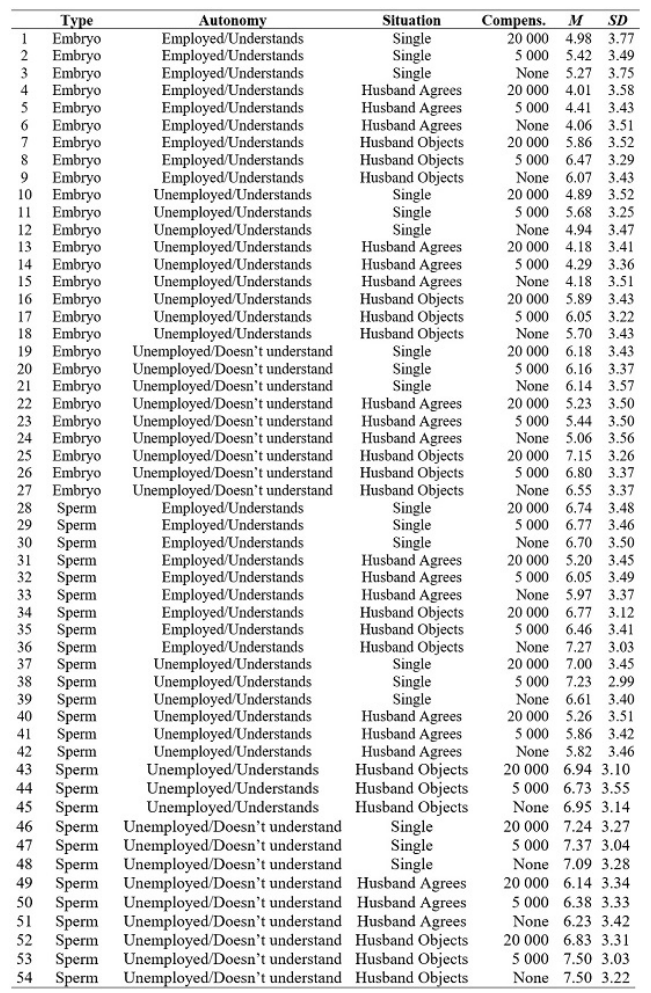

\section{Annex B}

\section{Main Results of the ANOVAs Conducted at the Cluster Level and at the Overall Level}

\begin{tabular}{|c|c|c|c|c|c|}
\hline Cluster and Factor & $d f$ & $M S$ & $F$ & $p$ & $\eta_{p}^{2}$ \\
\hline \multicolumn{6}{|c|}{ Cluster Type of Surrogacy } \\
\hline Type (T) & 1 & 15073.21 & 531.75 & 0.001 & 0.89 \\
\hline Autonomy (A) & 2 & 551.92 & 36 & 0.001 & 0.36 \\
\hline Family (F) & 2 & 644.92 & 43.48 & 0.001 & 0.4 \\
\hline Compensation (C) & 2 & 21.7 & 2.51 & 0.09 & 0.04 \\
\hline T x A & 2 & 188.82 & 17.18 & 0.001 & 0.21 \\
\hline$T \times F$ & 2 & 272.72 & 25.84 & 0.001 & 0.29 \\
\hline $\mathrm{A} \times \mathrm{F}$ & 4 & 62.19 & 7.46 & 0.001 & 0.1 \\
\hline $\mathrm{TxC}$ & 2 & 140.52 & 13.19 & 0.001 & 0.17 \\
\hline $\mathrm{T} \times \mathrm{F} \times \mathrm{C}$ & 4 & 83.25 & 10.29 & 0.001 & 0.14 \\
\hline \multicolumn{6}{|l|}{ Cluster Family Context } \\
\hline Type (T) & 1 & 1758.23 & 95.78 & 0.001 & 0.36 \\
\hline Autonomy (A) & 2 & 1361.17 & 82.59 & 0.001 & 0.33 \\
\hline Family (F) & 2 & 5421.97 & 159.12 & 0.001 & 0.49 \\
\hline Compensation (C) & 2 & 69.52 & 6.36 & 0.002 & 0.04 \\
\hline T X A & 2 & 74.72 & 8.55 & 0.001 & 0.05 \\
\hline $\mathrm{T} \times \mathrm{F}$ & 2 & 155.44 & 21.33 & 0.001 & 0.11 \\
\hline \multicolumn{6}{|c|}{ Cluster Always a Moral Problem } \\
\hline Type (T) & 1 & 885.79 & 51.94 & 0.001 & 0.34 \\
\hline Autonomy (A) & 2 & 128.38 & 16.24 & 0.001 & 0.14 \\
\hline Family (F) & 2 & 357.48 & 26.34 & 0.001 & 0.21 \\
\hline Compensation (C) & 2 & 24.36 & 2.83 & 0.06 & 0.03 \\
\hline TxF & 2 & 53.14 & 8.56 & 0.001 & 0.08 \\
\hline $\mathrm{A} \times \mathrm{F}$ & 4 & 28.29 & 5.59 & 0.001 & 0.05 \\
\hline \multicolumn{6}{|l|}{ Cluster Undetermined } \\
\hline Type (T) & 1 & 0.15 & 0.01 & 0.91 & 0 \\
\hline Autonomy (A) & 2 & 24.08 & 2.17 & 0.12 & 0.02 \\
\hline Family (F) & 2 & 49.32 & 3.30 & 0.04 & 0.03 \\
\hline Compensation (C) & 2 & 88.23 & 7.37 & 0.001 & 0.07 \\
\hline \multicolumn{6}{|l|}{ Overall } \\
\hline Cluster (G) & 3 & 10289.92 & 222.93 & 0.001 & 0.61 \\
\hline Type (T) & 1 & 10909.62 & 598.52 & 0.001 & 0.59 \\
\hline Autonomy (A) & 2 & 994.72 & 75.81 & 0.001 & 0.15 \\
\hline Family (F) & 2 & 2694.75 & 121.47 & 0.001 & 0.22 \\
\hline Compensation $(\mathrm{C})$ & 2 & 103.48 & 10.07 & 0.001 & 0.02 \\
\hline $\mathrm{G} \times \mathrm{T}$ & 3 & 3300.88 & 181.09 & 0.001 & 0.56 \\
\hline $\mathrm{G} \times \mathrm{A}$ & 6 & 259.69 & 19.79 & 0.001 & 0.12 \\
\hline $\mathrm{G} \times \mathrm{F}$ & 6 & 748.55 & 33.74 & 0.001 & 0.19 \\
\hline $\mathrm{G} \times \mathrm{T} \times \mathrm{A}$ & 6 & 42.08 & 4.76 & 0.001 & 0.09 \\
\hline GxT $\times F$ & 12 & 77.21 & 9.7 & 0.001 & 0.06 \\
\hline
\end{tabular}

\section{Notes}

